\title{
Magmatic interaction in peralkaline syenites of the Junguni Complex, Malawi
}

\author{
BENJAMIN F. WALTER ${ }^{1}$, R. JOHANNES GIEBEL ${ }^{2}$, MiCHAEL
} A.W. MARKS, GEGOR MARKL ${ }^{3}$

${ }^{1}$ Karlsruhe Institute for Technology (KIT), Adenauerring 20b, 76131 Karlsruhe, Germany, b.walter@kit.edu

${ }^{2}$ Technical University of Berlin (TUB), Ernst-Reuter-Platz 1, 10587 Berlin, Germany, r.j.giebel@tu-berlin.de

${ }^{3}$ Eberhard Karls University Tübingen, Wilhelmstr. 56, 72074 Tübingen, Germany, michael.marks@uni-tuebingen.de

Junguni is a peralkaline ring complex in the Late Jurrassic Early Cretaceous Chilwa Alkaline Province (Malawi). Rocks of the main complex consist mainly of alkali feldspar, nepheline, sodalite (replacing feldspar in a late, probably hydrothermal stage), aegirine, biotite, rare amphibole, and a range of accessory minerals including titanite (miaskitic composition). A satelite plug (Kadongosi) comprises partly eudialyte-bearing syenites, which is a clear mineralogical contrast to the eudialyte-free rocks of the main Junguni body. The primary mineral assemblage in these rocks consists of $\mathrm{K}$ dominated alkali feldspar, aegirine-augite, eudialyte and titanite (I), classifying the rocks as transitional agpaites. The mineral assemblage is strongly overprinted (probably by a successive magma batch), resulting in a secondary assemblage of alkali feldspars, nepheline, aegirine, magnesioarfvedsonite, biotite, titanite (II) and fluorite, with accessory $\mathrm{Zr}$ minerals (e.g., rosenbuschite). Hence, it shows mineralogical and mineral chemical similarities to the rocks of the main body probably indicating an interaction of magmas of different evolutionary stages during emplacement. While the Kadongosi rocks may bear relicts of an earlier evolutionary stage of the complex, the main Junguni rocks appear to preserve only the last magmatic event. However, the interpretation of an evolutionary sequence would be contrary to the generally assumed evolution of peralkaline magmas (miaskitic to agpaitic, not vice versa) and would require an adequate explanation. Alternatively, three completely independent peralkaline magma batches coexist in the Junguni complex. In this context, an understanding of the actual relationship and interaction between the different magmas may provide valuable insights into the peralkaline system. 